\title{
Educational Practices on Ethnic-racial Relations and the English Language Teaching through Image and Literature in an EFL Classroom
}

\author{
Jânderson Albino Coswosk \\ Researcher and Professor of Basic, Technical and Technological Education, Department of Languages, Instituto Federal \\ de Educação, Ciência e Tecnologia do Espírito Santo, Alegre-ES, Brazil \\ Correspondece: Jânderson Coswosk, Coordenadoria Geral de Ensino, Instituto Federal do Espírito Santo - Campus de \\ Alegre - Rodovia Cachoeiro/Alegre, km 48 - Rive, Alegre, ES - Brazil - Zip Code: 29520000.
}

Received: March 31, 2020 Accepted: April 14, 2020 Online Published: April 20, 2020

doi:10.11114/ijecs.v3i1.4800 URL: https://doi.org/10.11114/ijecs.v3i1.4800

\begin{abstract}
The article analyzes the unfoldings of the teaching project Introducing Literatures in English, held in 2018 at the Federal Institute of Espírito Santo (IFES), based in Alegre-ES, Brazil. The project aimed at promoting the improvement of reading, writing and speaking skills of English as a foreign language (EFL) learners, departing from African Literature in English and photography, so that they had the opportunity to improve their language skills while developing a broader discussion on Africa's ethnic-cultural and linguistic diversity, building a viewpoint about the African continent less tied to colonialism, slavery, apartheid and victimization.

For reading and written analyses, the students took into consideration the photo-book Another Africa (1998), with photographs by Robert Lyons and poems by Chinua Achebe (1930-2013). Based on the poems and photographs brought to light in Another Africa, I analyzed 1) the students' multimodal reading process, by connecting images generated by poems and photographs and written and oral texts the students produced around them; 2) the students' reception of the poems, considering Achebe's constant use of code-switching and 3) the construction of new viewpoints around Africa elaborated by the students, bearing in mind the importance of the role of language, memory and history, oral and literary traditions when it comes to African writers and a new perspective concerning the colonial legacy and its impact on English language.
\end{abstract}

Keywords: multimodal approach, code-switching, visual and written texts

\section{Introduction}

\subsection{The image of Africa}

As Chinua Achebe had already affirmed in An Image of Africa: Racism in Conrard's Heart of Darkness (1990a), the textuality produced by colonial empires fixed stereotyped images of native peoples who inhabited the Americas, as well as of African territories and peoples. Starting from Heart of Darkeness (1899) by Joseph Conrard (1857-1824), Achebe (1990a) explores Western portraits of the African continent in frames that place it as Europe's antithesis, a space without histories, cultures and literatures.

As we face literature as a practice of conceiving the world, as well as a way of producing memory (Erll, 2011), one may realize that Achebe's aesthetic-political project goes in the opposite direction of these instituted memories and negative images created around peoples victimized by colonization. Starting from a scope that highlights a very diverse cultural and literary history of the African continent, but with his feet always fixed on Nigeria's Igbo portion, Chinua Achebe has exposed other images of Africa in his critical essays, novels and short stories in order to confront imaginary regimes that dehumanize African peoples in the Western mainstream.

Achebe (1990b) reports how much his imagination and writing were contaminated by Western literature. There is, according to him, only one idea about Africa in the West, which is perpetuated through stereotypes around hegemonic appropriations of the signs of Africanity. Because of colonial inheritance and slavery, Africa continues to be seen by the West through the lens of inferiority. This way of seeing takes a new shape with racialism printed in spaces where colonialism invented and perpetuated their inferiority, with the purpose of justifying its "civilizing" endeavor to exploit enslaved human beings (Achebe 1965, 1984, 1990c; Appiah 2014). Printed, too, in literature, these stereotypes make African characters "expendable" (Adichie 2008). 
Achebe emphasizes how easily stereotyped images of Africa move from the literary support to hegemonic media, especially in the United States and Europe. However, in the same way that these negative images travel through different media, the insurgency of other images about the African continent has entered the printed and virtual circuits of the West through contemporary African diasporas. Bryce (2008) and Adesanmi \& Dunton (2008) point out that there is an emerging literary scene in Nigeria, stemming from the interest of Nigerians in creative writing courses, as well as the strengthening of the domestic Nigerian literary market and the exchange of printed books' distribution for accessing them on the web. In addition to the images of Africa circulating in literature, Nigeria has the third largest film production in the world. Nollywood, as it became known, has grown considerably in recent decades due to films that tell stories of Africa from an African perspective (Akinola, 2013).

Before such a contemporary imagery insurgency that portrays Africa far from stereotypes, Chinua Achebe's work was already consolidated in the West, mainly after the Nigerian-Biafran War (1967-1970) and his performance as a professor in American universities. However, it was with the launching of Another Africa that Achebe's ideas about the place where he was born took on a proportion not seen before. In collaboration with the photographer Robert Lyons, Achebe gathered poems and photos that revealed traces of Africa not covered by the Western narrative. With decentralized and discontinuous divisions of photos and poems from/about the continent, Another Africa does not bring, in the beginning, subtitles that grant the reader/viewer an ethnographic desire to map images and poems, merging them as if they could be combined. At the end of the book, the reader has access to the titles of the photographs and places where they were taken, and after contemplating them without such knowledge, s/he can even draw maps of the continent and know exactly where people and places in the photos are from and what the landscapes are about. From Senegal, Burkina Faso, Kenya, Tanzania or Sudan, the book brings unpretentious images and poems, which displace the continent and those who inhabit it from old perspectives woven throughout European colonialism in Africa and which were carried and perpetrated until contemporary times in images and texts.

\subsection{Africa and the Brazilian Context}

Considering the implementation of the Brazilian Federal Law 10.639/03, which deals with the teaching of Afro-Brazilian and African history and culture and emphasizes the importance of black culture in the formation of Brazilian society, as a teaching project, Introducing Literatures in English consisted of presenting not usual canonical works, but Achebe's writing and diction experiences in his poems and Lyons's photographic perceptions simultaneously as fictionalizations of the post-colonial experience in Anglophone Africa, without letting coloniality's heritage stand out from the continent's resistance to the colonial legacy.

Even though the circulation of goods, cultures and information have been fueled the contact of Brazilian high school EFL students with a dizzying literary production in English in recent years and, despite the fact that Brazilian cultural diversity and artistic production are completely enveloped by African traces, Africa still remains unknown for Brazil. Both the textbooks distributed in public schools and the photo-filmography we consume about African countries and peoples are still loaded with negative images around them, being confined in the period when European explorers crossed the Atlantic Ocean and kidnapped millions of Africans for slave labor. Since 2010, when Brazilian population recognized itself as mostly black, Brazil has been reviewing its own history and debating the phantom of mythological "racial democracy" that still haunts its hegemonic discourse (Htun, 2004).

As studies in the field of literature (Wenzel, 2006; Fasan, 2010; Farinde \& Ogunsiji, 2012; Dalley, 2013), anthropology (Griswold, 1992; Sulaiman, 2012), cultural studies (Hall, 1997), among so many others have pointed out, many artistic and academic productions have composed over the years a portrait of how structural racism, arising from racial theories and slavery, operates so that Afro-Brazilian and indigenous populations are less socially favored. Since "images are part of daily life and carry social and cultural meanings, beliefs, values and power relations" (Lins de Almeida \& Souza, 2017, p. 206), this article analyzes the application of reading and writing strategies that bridge image and literature (Schøllhammer, 2007) with EFL high school students at IFES. Given the lack of emphasis on visual structures (Kress \& van Leeuwen, 2006) and debates on racial issues in day-by-day EFL classes in Brazil (Ferreira, 2007), the combination of Achebe's poems and Lyons's images impacted the students significantly, alerting them to the importance of the role of language, memory and history, oral and literary traditions when it comes to African writers and helped them to build a new perspective concerning the colonial legacy and its impact on English language.

\section{Method}

From March to May 2018, the teaching project gained a course format, with two weekly classes of 50 minutes each and included a selection of 18 students from 16 to 17 years old, which were in their third year of high school technical courses at IFES. For selection purposes, interviews and written tests were applied, and students should have intermediate or advanced English and interest in reading, writing, and discussing literary texts in English. Under the considerations of Kress \& van Leeuwen (2006), Schøllhammer (2007) and Lins de Almeida \& Souza (2017), the lectures on Another 
Africa's authors, the connections between Achebe's exile in the United States and the collaboration between a writer and a photographer took into account only the use of stereotyped images of the African continent over the last five centuries compiled by Hall (1997). Based on images collected and commented by Hall (1997) in his essay The Spectacle of the Other, and after reading and discussing them, the students carried their discussion concerning their previous viewpoints about the African continent.

Secondly, the students learned about the Anglophone portion of the African continent and were put in contact with Another Africa in digital version. Initially, the students read all the book chapters, based only on the images, in order to develop the learning of visual literacy in the first place (Kress \& van Leeuwe, 2006; Almeida 2009; Lins de Almeida \& Souza, 2017).

Then the students encountered Achebe's poems and were able to read them in comparison with the photographs, forming a true mosaic of words and images. When dealing with the poem A Wake for Okigbo (Lyons \& Achebe 1998, p. 49), they came into contact with a stylistic resource specific to African English-speaking writers who, when they decide to write in the colonizer language (in this case, in English), they often choose to mix their native language with the "adopted" one (Ibhawaegbele \& Edokpayi, 2012; Farinde \& Ogunsiji, 2012). This takes place because, in the Nigerian case, writers opt to mark their native language over the colonizer's in order to also mark their peoples' resistance to the colonial judgment (Achebe 1965, 2012a, 2012b; Whitney, 2010). This stylistic feature draws on what David Crystal (2003, p. 164) recognizes as code-switching: "the process in which people rely simultaneously on two or more languages to communicate with each other".

Finally, the students produced a one-hour debate in the last two classes concerning the visual and textual experience they had, in addition to having produced a text between 15 to 20 lines about their experiences and changing their points of view.

\section{Results}

Initially, the students had great difficulty in formulating outdated readings from the knowledge they already had about Africa and the images presented by Hall (1997), exposed in the beginning of our dialogues. There were long discussions about what the colonial imposition did to format the continent geographically and historically, but mostly in the images and conceptions that the West produced about Africa.

When such images were contrasted with Robert Lyons's photographs, the impression they had already built up during school life was unstructured, as such Another Africa's images do not correspond to those in which the African continent was exposed by coloniality. In the debates and new readings, students began to reflect on the imagery produced around Africa by European travelers, not to mention those in which the continent can speak for itself. The answers students gave after the contrast of images became more critical.

Upon reading Achebe's poems and encountering code-switching, 10 students were unable to establish a more fluid understanding of the poem A Wake for Okigbo (Lyons \& Achebe 1998, p. 49), which had to be worked on during the period of two classes to discuss metaphors and linguistic hybridities that the poem brings. Furthermore, oral and written texts produced by the students aligns with a notion that teaching foreign language from a multimodal approach can contribute to the improvement of critically reading a visual or written text (Almeida 2009; Lins de Almeida \& Souza 2017).

\section{Conclusion}

By combining Another Africa's poems and photographs, the teaching project Introducing Literatures in English enabled students to i) have a brief literary overview of the contemporary English-speaking African diaspora (Oyebade, 2003; Falola \& Heaton, 2008; Falola \& Aderinto, 2010), in order to be able to establish connections between these productions and those of their own country; ii) create reading strategies for Achebe's poems, as they acquire greater familiarity with English in literary texts; iii) develop readings of Lyons's images through a multimodal approach, which may provide them other ways of reading and other textual constructions when dealing with photographic images; iv) expand their critical sense in the face of texts and readings, promoting further discussions in the classroom. Moreover, the students could gain, through visual and literary texts, new vocabulary and morphosyntactic acquisition when it comes to English language.

\section{References}

Achebe, C. (1965). English and the African Writer. Transition, 18, 27-30.

Achebe, C. (1984). The Trouble With Nigeria. London: Heinemann.

Achebe, C. (1990a). An Image of Africa: Racism in Conrad's Heart of Darkness. In: Hopes and Impediments: Selected Essays. New York: Anchor Books/Random House, 1-20.

Achebe, C. (1990b). What Literature Has Got To Do With It?. In: Hopes and Impediments: Selected Essays. New York: 
New York: Anchor Books/Random House, 154-170.

Achebe, C. (1990c). Named for Victoria, Quen of England. In: Hopes and Impediments: Selected Essays. New York: New York: Anchor Books/Random House, 30-39.

Achebe, C. (2012a). Política e políticos da língua na literatura africana. In: A educação de uma Criança sob o Protetorado Britânico. Trad. Isa Mara Lando. São Paulo: Cia. Das Letras, 100-110.

Achebe, C. (2012b). O que é a Nigéria para mim? In: A educação de uma Criança sob o Protetorado Britânico. Trad. Isa Mara Lando. São Paulo: Cia. Das Letras, 46-53.

Adesanmi, P., \& Dunton, P.C. (2008). Introduction: Everything Good Is Raining: Provisional Notes on the Nigerian Novel of the Third Generation. Research in African Literatures, 39, vii - xii. https://doi.org/10.2979/RAL.2008.39.2.VII

Adichie, C. N. (2008). African "Authenticity" and the Biafran Experience. Transition, Issue 99, 42-58. https://doi.org/10.2979/TRS.2008.-.99.42

Akinola, O. (2013). The Rebirth of a Nation: Nollywood and the Remaking of Modern Nigeria. The Global South, 7(1), 11-29. https://doi.org/10.2979/globalsouth.7.1.11

Almeida, D.B.L. (2009) Do texto às imagens: as novas fronteiras do letramento visual. In: R.C.M Pereira and P. Roca (Eds.) Linguística Aplicada: Um Caminho com Diferentes Acessos (pp. 173-202). São Paulo, Contexto.

Appiah, K. A. (2014). Na casa de meu pai: a Africa na filosofia da cultura. Trad. Vera Ribeiro. Rio de Janeiro: Contraponto.

Bryce, J. (2008). "Half and Half Children": Third-Generation Women Writers and the New Nigerian Novel. Research in African Literatures, 39(2), 49-67. https://doi.org/10.2979/RAL.2008.39.2.49

Crystal, D. (2003). English as a global language. Cambridge: Cambridge University Press. https://doi.org/10.1017/CBO9780511486999

Dalley, H. (2013). The Idea of "Third Generation Nigerian Literature": Conceptualizing Historical Change and Territorial Affiliation in the Contemporary Nigerian Novel. Research in African Literatures, 44(44), 15-34. https://doi.org/10.2979/reseafrilite.44.4.15

Erll, A. (2011). Memory in Culture. Hampshire: Palgrave Macmillan. https://doi.org/10.1057/9780230321670

Falola, T. \& Heaton, M. M (2008). A History of Nigeria. London: Cambridge University Press. https://doi.org/10.1017/CBO9780511819711

Falola, T. \& Aderinto, S. (2010). Nigeria, Nationalism, and Writing History. New York: University of Rochester Press.

Farinde, R. O. \& Ogunsiji, Y. (2012). The Linguistic Debate of Nigerian Literary Writers. British Journal of Arts and Social Sciences, 6(1), 81-87.

Ferreira, A. J. (2007). What has race/ethnicity got to do with EFL teaching?. Linguagem \& Ensino, 10(1), 211-233.

Fasan, R. O. (2010). Mapping Nigeria Literature, Africa Nebula, 1(1), 33-43.

Griswold, W. (1992). The Writing on the Mud Wall: Nigerian Novels and the Imaginary Village. American Sociological Review, 57(6), 709-724. https://doi.org/10.2307/2096118

Hall, S. (1997). Representation: cultural representations and signifying practices. London: Sage/The Open University.

Htun, M. (2004). From "Racial Democracy" to Affirmative Action: Changing State Policy on Race in Brazil. Latin American Research Review, 39(1), 60-89. https://doi.org/10.1353/lar.2004.0010

Ibhawaegbele, F.O. \& Edokpayi, J. N. (2012). Code-Switching and Code-Mixing as Stylistic Devices in Nigerian Prose Fiction: A Study of Three Nigerian Novels. Research on Humanities and Social Sciences, 2(6), 12-18.

Igboanusi, H. (2001). The Igbo Tradition in the Nigerian Novel. African Study Monographs, 22(2), 53-72.

Kress, G and van Leeuwen, T. (2006) Reading Images: The Grammar of Visual Design (2 $2^{\text {nd }}$ edn). London, Routledge. https://doi.org/10.4324/9780203619728

Krishnan, M. (2014). Negotiating Africa Now. Transition, Issue 113, 11-24. https://doi.org/10.2979/transition.113.11

Lins de Almeida, D. B. \& Souza, V. G. (2017). Toward a Multimodal Critical Approach to the Teaching of EFL in Brazil. In: Kamhi-Stein, L. D. et al. (Eds.). English Language Teaching In South America: Policy, Preparation and Practices (pp. 206-218). Bristol; Blue Ridge Summit: Multilingual Matters. https://doi.org/10.21832/9781783097982-014

Lyons, R. \& Achebe, C. (1998). Another Africa. New York: Anchor Books. 
Oyebade, A. (2003). A Retrospect on Colonial Nigeria. In OYEBADE, A. (Ed). The Foundations of Nigeria: Essays in honor of Toyin Falola (pp. 1-15). Asmara: Africa World Press.

Schøllhammer, Karl Erik. (2007). Além do visivel: o olhar da literatura. Rio de Janeiro: 7Letras.

Sulaiman, F. R. (2012). Internationalization in Education: The British Colonial Policies on Education in Nigeria $1882-$ 1926. Journal of Sociological Research, 3(2), 84-101. https://doi.org/10.5296/jsr.v3i2.2222

Wenzel, J. (2006). Petro-magic-realism: toward a political ecology of Nigerian literature. Postcolonial Studies, 9(4), 449464. https://doi.org/10.1080/13688790600993263

Whitney, J. A. (2010). Mongrel Canon. World Policy Journal, 27(3), 19-24. https://doi.org/10.1162/wopj.2010.27.3.19

\section{Copyrights}

Copyright for this article is retained by the author(s), with first publication rights granted to the journal.

This is an open-access article distributed under the terms and conditions of the Creative Commons Attribution license (http://creativecommons.org/licenses/by/4.0/). 